\title{
THE CROSS-CULTURAL COMPARISON OF DIFFERENT COMMUNICATION STYLES AMONG CONVENTION AND VISITORS' BUREAUS (CVB)
}

\author{
Krzysztof Celuch* (1) http://orcid.org/0000-0002-5307-2900 \\ Aldona Glińska-Neweś** ittp://orcid.org/0000-0002-5415-1563 \\ Mathilda van Niekerk*** () http://orcid.org/0000-0003-4038-6350
}

\begin{abstract}
Background. Convention and Visitors Bureaus (CVB) and Destination Marketing Organisations (DMOs) play a crucial role in marketing and promoting a city, region, or country through creating an image of the destination as an attractive target and meeting area. The effectiveness of the overall process is influenced, among others, by the efficiency of the CVBs' communication with its key stakeholders.
\end{abstract}

Research aims. The aim of the paper is to discuss the differences in CVBs' communication styles, particularly regarding the extent to which the communication is diversified and personalised depending on different regions of the world.

Methodology. The comparative analysis is based on a survey conducted among 89 CVB representing Africa, Asia, Australia, Europe, the Middle East, North America, and South America. While in most of the studied organisations communication with their members should be effective, the importance of this effectiveness among organisational goals varies. It is among strategic goals for European, Asian and Australian DMOs. Asian organisations personalise their communication styles regarding specific members, so the content of the communication is tailored. Interestingly, for the Asian units it is usually irrelevant for the communication efficiency how many members they have. In contrast, for European and North American organisations the number of members should be lower.

Key findings. The picture presented on a basis of our study results is interesting and complex. While in most of the studied organisations communication with their

\footnotetext{
"Faculty of Economic Sciences and Management, Nicolaus Copernicus University in Torun, Gagarina 13a, Toruń 87-100, Poland. E-mail: kceluch@umk.pl

** Faculty of Economic Sciences and Management, Nicolaus Copernicus University in Torun, Gagarina 13a, Toruń 87-100, Poland. E-mail: aldona.glinska@umk.pl

**** Rosen College of Hospitality Management, University of Central Florida, USA. E-mail: mathilda.vanniekerk@ufc.edu
} 
members should be effective, the importance of this effectiveness among organisational goals vary. It is among strategic goals for European, Asian, and Australian DMOs. Asian organisations personalise their communication styles regarding specific members, so the content of the communication is tailored. Interestingly, for the Asian units it is usually irrelevant for the communication efficiency how many members they have. In contrary, for European and North American organisations the number of members should be lower.

Keywords: destination marketing, communication, convention bureau.

JEL Codes: C1, M14, O15

\section{INTRODUCTION}

Professionals working in the tourism and hospitality industry need to regularly communicate effectively with one another, with their stakeholders, and with tourists (Fernández-Cavia et al., 2017). The strength of their relationship is often built on the basis of formal and informal communication and the ability to establish trust in their business relationships. The exchange of information plays a very critical role in their success and communication allows for this interchange to occur. In order to form these bonds, a favourable environment is required to make necessary communication exchanges. Many times, tourism and hospitality professionals meet through professional organisations like Destination Marketing Organisations (DMOs) and/or Convention and Visitors Bureaus (CVB) that create networks for communication to flow (Volgger \& Pechlaner, 2014). They are global organisation that link tourism and hospitality stakeholders together and can co-create leisure and business events around the world/regions and cities (Lee et al., 2016). Often in these interactions, the notion of culture is ignored when communicating between professionals in different parts of the world which can reduce the effectiveness of the business performance (Samaha et. al., 2014).

\section{CONVENTION AND VISITORS' BUREAUS (CVB)}

"When we have a convention in town, it is as if an airplane flew overhead dropping dollar bills on everyone". This statement by a mayor of a US city proves the economic significance of organising such business tourism as conventions, conferences for the host-city (Kulshrestha \& 
Meena, 2017). It is quoted by many market commentators and analysts (Smith, followed by Davidson \& Cope, 2003). Indeed: figures contained in reports drafted on the basis of statistics (e.g. by the ICCA - International Congress and Convention Association, the UIA - Union of International Associations) indicate that the so-called congress tourist, i.e. a convention or conference participant, spends a lot more money at the event location than an individual tourist (Rogerson, 2017). Notwithstanding the fact that his/her participation in the meeting has already been paid (average expenses per one conference participant acc. to ICCA amount to USD 736), and irrespective of whether such a participant has been invited by an association that he/she is a member of, a corporation or a public institution. It seems, therefore, that conference and congress business is the most profitable "slice" of the business tourism cake. But the question is who brings the business to the country / region / city?

The group of entities playing an important role in the business tourism industry comprises of CVBs and DMOs which deal with promoting meetings and events and marketing the destination to the tourism and bringing them to a given city, region, or country (Kulshrestha \& Meena, 2017). Their role differs depending on the geographical region they operate in, but their activity focuses on promotion (Lee et al., 2016). Its key element is the contact with customers and relaying the latest information on entities operating in the meetings industry. On the other hand, customers use CVBs and DMOs as a source of information on incentive travel programmes, venue capacity, or number of rooms in respective hotels (Celuch, 2015).

One of the most important definitions is by Ford and Peeper and it focuses on responsibilities: A CVB is an organisation that both by law and by design is responsible for marketing a destination (Ford \& Peeper, 2008; Lee et al., 2016; Rogers \& Davidson, 2015). This task is not only a big challenge but is also the reason that so many CVB executives spend a lot of time explaining their organisations' functions, roles, and expenses. Repeatedly we have heard the executives - both successful and less successful - voice the same concern about how much time it has taken them to explain what they do, especially to politicians controlling their purse strings. Many said that the amount of time they spent was unreasonable (Ford \& Peeper, 2008). However, the most important role that a CVB plays is the communication with its stakeholders and a successful combination of theory and practice. 


\section{THEORIES OF SOCIAL COMMUNICATION IN ORGANISATIONS}

On the basis of a specified communication architecture, theories regarding the foundations of social communication in an organisation have been selected. The following models will be presented and characterised together with the code forms, contexts, and relation systems specified to the American and European style of communication:

- R. Jakobson's model (1960),

- H.D. Lasswell's model (1948),

- R.R. Gesteland's model (2012),

- G. Hofstede and G.J. Hofstede's model.

Roman Jakobson's theory and model were created in 1960; upon creating the model, its author focused above all on the meaning of the communication structure. According to J. Fiske, that model (Fiske, 1990) is a double one. He [Jakobson] starts by modelling the constitutive factors in an act of communication. These are the six factors that must be present for communication to be possible (sender, receiver, context, message, contact, and code). He then models the functions that this act of communication performs for each factor (emotive, conative, referential, poetic, phatic, and metalingual). The factor model together with the functions looks as follows (Figure 1).

The derivative model, mentioned due to its frequent appearance, is a simplified version of the Jakobson's model presented by Harold D. Laswell. Lasswell developed another widely quoted early model.

Context (referential function)

Message (poetic function)

Sender (emotive function)-------------Receiver (conative funtion)

Contact (phatic function)

Code (metalingual function)

Figure 1. The Jakobson Model of Communication

Source: Berger, 2018, p. 120. 
His, though, is specifically one of mass communication (Lasswell, 1948). He argues that to understand the processes of mass communication we need to study each of the stages in his model (McQuail \& Windahl, 2015; Figure 2).

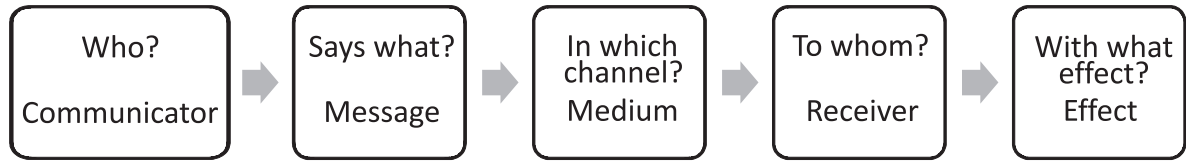

Figure 2. The Lasswell's formula with corresponding elements of the communication process

Source: Lasswell, 1948, p. 52.

These two models describe the links between the American and European meetings and events industry and will be used in the conducted research. These models are very helpful to understand mass communication (McQuail \& Windahl, 2015) present in the meetings industry, taking into consideration the meeting goals (content, product, and motivation), are an attempt at combining business tourism (already analysed on numerous occasions) with event management and the creation of incentive travel. The proposed model is based on the cooperation among the participants of the meetings industry (customer, agent, venue, supplier) and an exchange of information and cooperation with CVBs and the media (Celuch, 2015).

An analysis of cooperation between respective participants of the meetings industry has already been discussed in the literature; however, it should also mention the entities which participate indirectly in coordinating, promoting, and obtaining meetings and business events. These interdependencies overlap and form the field of information exchange (Celuch, 2016b). All entities included in the model of cooperation between the participants of the meetings industry are dependent on one another (Celuch, 2016b). When describing the needs connected with the meeting goal and communication process where CVBs are involved, the customer determines its category in accordance with the "content, product, motivation" division and only on that basis they select the organiser, venue, and subcontractors specialising in the organisation of the given meeting type (Figure 3).

All in all, the starting point in the context of efficiency and profitability of using respective communication tools is always a precise definition 
of the communication goals. CVBs and DMOs have a more and more important role on the international market (Volgger \& Pechlaner, 2014). Therefore, it is necessary to analyse the meetings industry from the point of view of DMOs globally. For this reason, we investigate the influence of culture on communication in inter-organisational relationships.

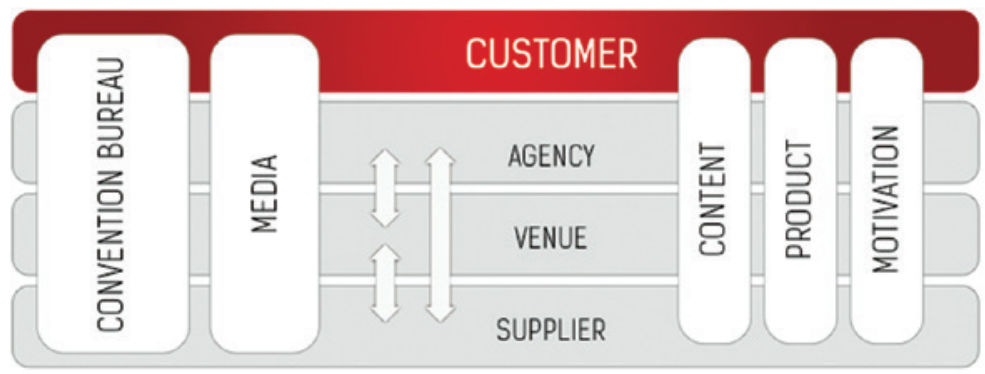

Figure 3. Model of cooperation between the participants of the meetings industry broken down by goals

Source: Celuch, 2014, p. 33.

\section{CULTURE INFLUENCE ON COMMUNICATION IN INTER-ORGANISATIONAL RELATIONSHIPS}

Culture and communication remain in a complex mutual relationship. Communication is considered as a mirror of a culture (Ferraro, 2006) as through both verbal and non-verbal communication styles members of a community express their values, i.e. they manifest their culture. On the other hand, culture and its specific dimensions influence those verbal and non-verbal communication styles in an organisation (Ting-Toomey $\&$ Dorjee, 2018). Regarding the aim of this paper, it will focus on the latter perspective. Notably, it will focus on particular dimensions of culture shaping the way how people communicate, with a special emphasis on behaviours related to inter-organisational relationships.

Cross-cultural and intercultural management studies are based, in most cases, on frameworks created on the ground of social anthropology (Tjosvold, 2017). Thus, dimensions of culture identified in those frameworks explain business behaviours in rather general terms, i.e. they refer to values related to general problems, such as power and authority, concept of self, dealing with uncertainty etc. (Hofstede, 1997). At the 
same time, each of the dimension may affect, in a way, the process of interpersonal communication. For instance, dimensions related to authority, such as power distance (Hofstede) and formality (Gesteland, 2012), influence the process of interpersonal communication among people representing different hierarchical positions in an organisation. Among scarce dimensions referring directly to interpersonal communication it should mention high vs. low-context style (Hall, 1976). In a low-context culture words are more important than other means of expression and a communicator needs to be very explicit; in a high-context culture many things, particularly those contradictory or unpleasant, are left unsaid and a message is hidden in a whole social context rather than only in words. Importantly for this study high vs. low-context communication is usually connected with an approach to making business relationships. The latter may be described through a dimension of relationship- vs. deal-focus (RF-DF, Gesteland, 2012; Glinska-Newes et al., 2018).

Although relationships are important in business everywhere, members of different cultures perceive differently the nature of those relationships. In deal-focused (DF) cultures people are task-oriented, i.e. so they are interested in the economic and transactional side of a relationship. Thus, they are less interested in creating personal bonds with business partners. As a result, it is easy to make a direct initial contact with them, because they do not need to know their partners well before starting a business. Partners representing such culture get down to business straightaway. Though they may like to socialize with each other over meals or drinks, it is not necessary to get to know each other very well. Relationships are formalised, and partners rely primarily on written contracts. Those contracts are not personalised, i.e. any specific and individual differences are less considered. The communication style common for DF people is low-context.

In contrary to DF people, those representing relationship-focused (RF) culture deal only with business partners who they know and can trust. They feel very uncomfortable doing business with strangers, particularly foreigners, and they want to know their prospective business partners well before doing business with them. In such circumstances it takes time and patience to start a relationship which results in signing a contract. "In RF markets, first you make a friend, then you make a deal" (Gesteland, 2012, p. 34; Glinska-Newes et al., 2018). Such relationships have a strong personal component in addition to transactional aspects. Personal bonds are to maintain and strengthen throughout the entire 
time of cooperation, but they prevent difficulties and help in solving problems appearing on the way. Partners are treated in individualised way and even contracts may be treated with flexibility and modified in the course of their implementation (Gesteland, 2012). High-context communication is specific for $\mathrm{RF}$ people.

Deal-focused cultures are present in North and Western Europe, North America, Australia and New Zealand. Relationship-focused cultures are specific for Asia, Africa, and the Arab World. The rest of the world, i.e. rest of Europe and South America, are classified as moderate deal-focused. Taking this into account, a question arises if CVBs representing particular regions of the world build their communication strategies in line with characteristics assigned to them according to RF-DF dimension. Notably, do CVBs functioning in cultures categorized as RF communicate with their partners in a personalised way? Do CVBs functioning in cultures classified as DF use a less personalised style of communication? In the next paragraph we will look for the answers on a basis of a study conducted among CVB representing all regions of the world.

\section{METHOD}

The main aim of our study was to identify similarities and differences in communication activities conducted by CVB's representing particular regions and cultures of the world. Notably, an individual structured interview was used in order to collect respondent opinions on communication operations in the main areas of CVB's activities, including:

- communication with CVB members,

- geographical marketing,

- promotion of CVB products,

Specifically, the questionnaire questions referred to respondents' opinions on:

- membership, i.e. size of CVB related to its communication effectiveness,

- style of communication between CVB and its members, effectiveness and efficiency of this communication,

- frequency of communication related to statutory activities, organisation, marketing of products and content-related information,

- dissemination of information about CVB members. 
The aforementioned issues were evaluated mostly using 4- or 5-point Likert scale, unless the issue required another scale to be used. The study methodology and sample were chosen upon consultancy with the main industry associations, including: UIA - Union of International Associations, ICCA - International Congress and Convention Association, DMAI - Destination Marketing Association International, MPI - Meeting Professionals International. The aforementioned institutions were interested in the study results. The research sample of $89 \mathrm{CVB}$ representatives included (table 1 ).

Table 1. Research sample structure

\begin{tabular}{|c|c|c|c|c|c|}
\hline $\begin{array}{l}\text { Geographical } \\
\text { area of the } \\
\text { convention } \\
\text { bureaus }\end{array}$ & Number & $\%$ & Position of the respondents & Number & $\%$ \\
\hline North America & 18 & 20 & $\begin{array}{l}\text { Senior Executives (Executive Vice } \\
\text { President, Senior Vice President) }\end{array}$ & 27 & 30 \\
\hline South America & 29 & 33 & $\begin{array}{l}\text { Executives (Vice President, Senior } \\
\text { Director) }\end{array}$ & 22 & 25 \\
\hline Europe & 15 & 17 & $\begin{array}{l}\text { C-Level Executives (CEO/President, } \\
\text { CFO, CIO, CMO) }\end{array}$ & 14 & 16 \\
\hline Africa & 6 & 7 & $\begin{array}{l}\text { Senior Management (Director, Senior } \\
\text { Manager) }\end{array}$ & 8 & 9 \\
\hline Middle East & 5 & 6 & Mid-Level Government Administrators & 8 & 9 \\
\hline Asia & 9 & 10 & Senior Government Administrators & 5 & 6 \\
\hline \multirow[t]{2}{*}{$\begin{array}{l}\text { Australia and } \\
\text { New Zealand }\end{array}$} & 7 & 8 & $\begin{array}{l}\text { Professional Staff (Account Executive, } \\
\text { Project Manager, Specialist) }\end{array}$ & 4 & 4 \\
\hline & & & Support Staff & 1 & 1 \\
\hline Sex & & & Major areas of operations of DMO & & \\
\hline Female & 46 & 51 & North America & 18 & 20 \\
\hline \multirow[t]{2}{*}{ Male } & 43 & 49 & South America & 28 & 33 \\
\hline & & & Europe & 15 & 17 \\
\hline $\begin{array}{l}\text { Age of the } \\
\text { respondent }\end{array}$ & & & Asia & 9 & 10 \\
\hline $18-25$ & 12 & 14 & Middle East & 5 & 6 \\
\hline $26-35$ & 40 & 45 & Africa & 6 & 7 \\
\hline $36-50$ & 28 & 31 & Australia / NZ & 7 & 8 \\
\hline More 50 & 9 & 10 & $\mathrm{~N}=89$ & & \\
\hline
\end{tabular}

Source: authors' contribution. 
Due to the fact that people below 50 dominate both the tourism and hospitality industry, four age groups were created to be selected by the respondents. These characteristics presents also the age segmentation and clearly shows that $90 \%$ of all respondents are below 50 . We can therefore claim that the dynamic changes, numerous access channels, multimedia communication, or meeting expectations are particularly close to people of that age group today. Finally, CVB's and DMOs participating in the survey represented South America, North America, and Europe as the major areas of operations and activity (total: $69 \%$ ).

\section{RESULTS}

There were no differences among CVBs and DMOs representing specific regions concerning their efforts towards effective communication with their members. When asked to evaluate if they do their best to ensure effective communication between themselves and their members, $65 \%$ of the respondents answered "yes" and 15\% answered "definitely yes". The answer structure is presented in Figure 4.

However, in Figure 5 there were interesting differences among DMOs representing particular regions regarding importance of communication effectiveness as their organisation strategic goal. It was revealed

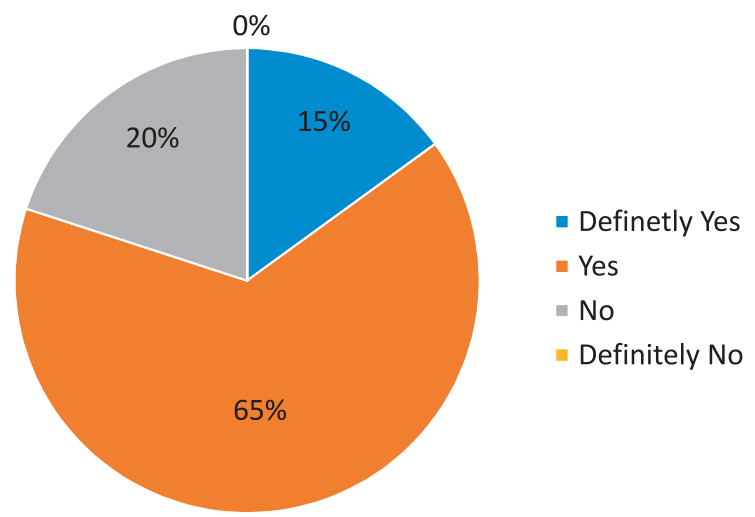

Figure 4. Answers to the question: "Do you do your best to ensure effective communication with your members?"

Source: own source. 


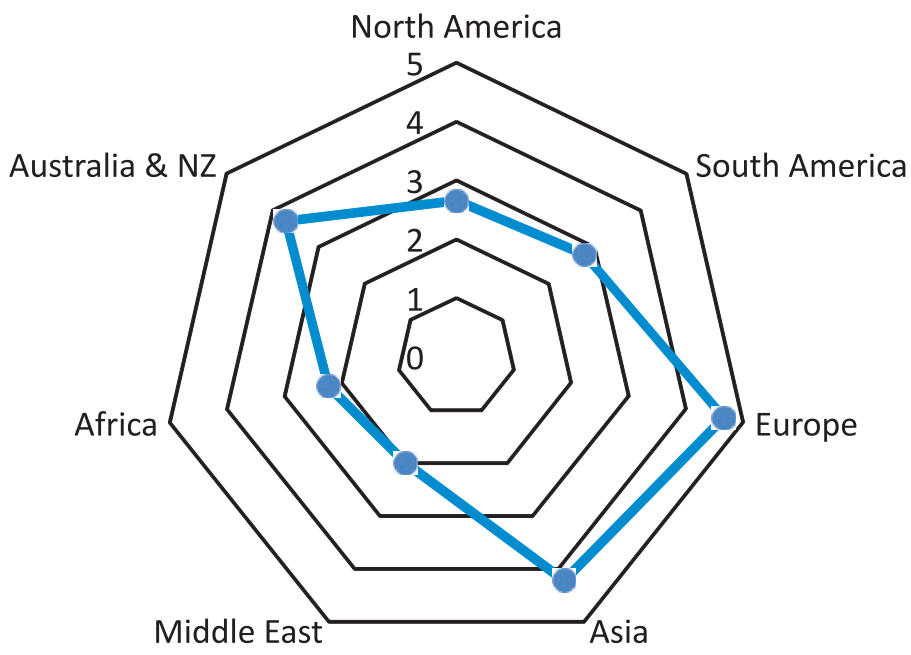

Figure 5. Importance of communication effectiveness as the organisation's strategic goal

Source: own source.

through answers for the next question. Effective communication is crucial, i.e. it is considered among the most important goals, mostly by European, Asian, and Australian organisations. It is the least important in the Middle East.

Interesting results were delivered through answers to the question regarding the number of members that DMOs should have to ensure the most effective communication. In Figure 6, the total sample $43 \%$ of participants answered that it should be between 31 and 50 members, and $30 \%$ - between 51 and 100 . At the same time $10 \%$ believe that the size of DMO and the number of its members does not matter at all. The least number of members is perceived as favourable by European and North American organisations, while "the number does not matter" mostly for Asian units.

The next sets of questions were regarding the style of communication with DMO members. Notably, respondents evaluated if they communicated with them in personalized manner. Concerning this matter we found large differences among the studied regions. Asian and African organisations communicate in the most personalised way, while North American and Australian units rarely personalise the content of communication (Figure 7). 
The above presented data is generally confirmed by the answer structure for the next question which concerned the tailored way of designing a content of communication with DMO members. Also, in this case Asian and African organisations admitted that their way of communicating with members is tailored, i.e. it is personalised regarding a member type, needs, or other traits (Figure 8).

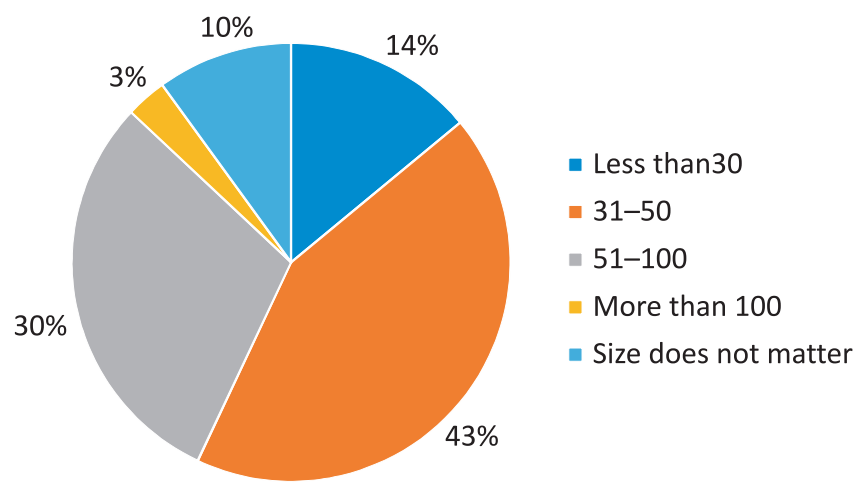

Figure 6. Number of members for effective communication

Source: own source.

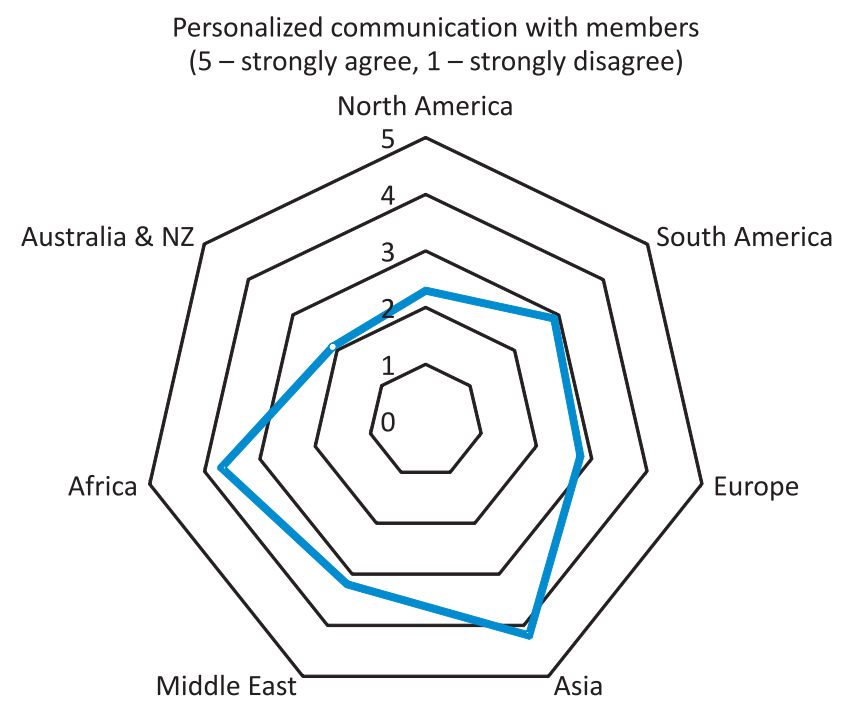

Figure 7. Personalised communication with members

Source: own source. 
To what extent your communication with members is tailored?

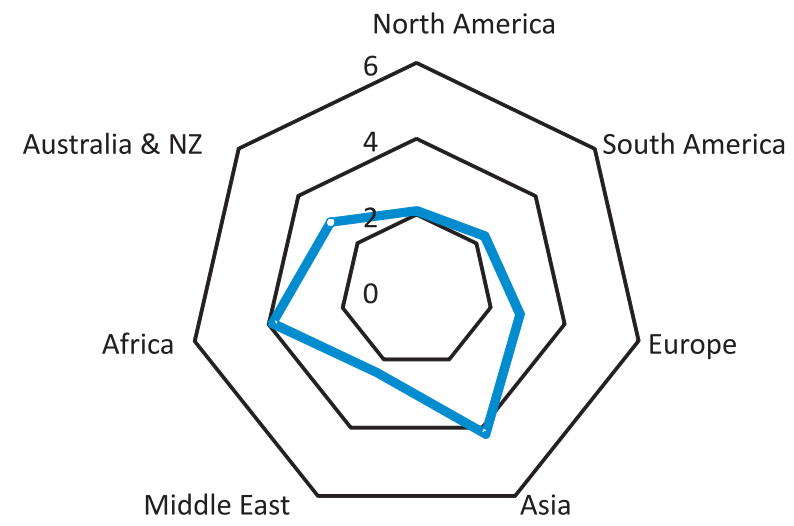

Figure 8. Extent of communication tailored to members

Source: own source.

\section{CONCLUSIONS}

The main aim of the study was to identify similarities and differences in communication activities conducted by CVBs and DMOs representing particular regions and cultures of the world. The picture presented on the basis of our study results is interesting and complex. While in most of the organisations studied communication with their members should be effective, the importance of this effectiveness among organisational goals varies. It is among strategic goals for European, Asian, and Australian DMOs. Asian organisations personalise their communication style regarding specific members, so the content of the communication is tailored. Interestingly, for the Asian units it is usually irrelevant for the communication efficiency how many members they have. In contrary, for European and North American organisations the number of members should be lower. Our aim was to identify if the communication style is correlated with DF-RF dimension. We assumed that $\mathrm{RF}$ characteristics are linked with a personalised communication style while $\mathrm{DF}$ is linked with low volume information. RF is true for Asia and Africa, but less for the Middle East. The latter was represented by units such as Dubai which are multicultural, that is why their characteristics based on culture frameworks may be less clear. 


\section{LIMITATIONS AND FUTURE RESEARCH}

Research conducted among the members of top industry destination marketing organisations is a great baseline to start working closely with them. Meetings and events industry is young enough to make comparisons and summaries. Certainly, there is a need to improve the communication style but one of the limitations that researchers can come across is the rather closed nature of the discussed group. It is really difficult to conduct the research among hospitality professionals because they stick together and are not willing to share their opinions about the structures they belong to. The authors have a plan to carry out a similar research among members of other bodies focused on destination marketing, incentive travel, or congresses. Apart from particular pieces which will focus on selected areas it is both possible and necessary to summarise all the results and prepare a bigger report. The authors have a plan to run a similar research among global convention and visitor bureaus in the coming years which are focused on destination marketing, incentive travel, or congresses.

\section{REFERENCES}

Adler, R.B. et al. (1998). Interplay. The Process of Interpersonal Communication. Fort Worth: Harcourt Brace College Publishers.

Beerli, A. \& Martín, J.D. (2004). Tourists' characteristics and the perceived image of tourist destinations: A quantitative analysis. A case study of Lanzarote, Spain. Tourism Management, 25(5), 623-636.

Berger, A.A. (2018). How jokes work? Seven humor theorists in search of a joke: Multidisciplinary perspectives on a humorous text. The Languages of Humor: Verbal, Visual, and Physical Humor, 36, 123-127.

Bigovic, M. \& Prašnikar, J. (2015). Predicting tourists' behavioural intentions at the destination level. Current Issues in Tourism, 18(8), 744-764.

Bill Xu, J. \& Chan, A. (2010). A conceptual framework of hotel experience and customer-based brand equity: Some research questions and implications. International Journal of Contemporary Hospitality Management, 22(2), 174-193.

Boo, S., Busser, J. \& Baloglu, S. (2009). A model of customer-based brand equity and its application to multiple destinations. Tourism Management, 30(2), 219-231. 
Celuch, K. (2014). Przemyst spotkań. Wiedza, produkt, motywacja. Warszawa: Grupy Uczelni Vistula.

Celuch, K. (2015). Managing Content, Product and Motivation in Meetings and Events Industry. Warsaw: Uczelnia Vistula.

Celuch, K. (2016b). Trendy w przemyśle spotkań na przykładzie segmentacji zarządzania spotkaniami biznesowymi. Ekonomiczne Problemy Turystyki, 1(33), 225-234.

Davidson, R. \& Cope, B. (2003). Business Travel: Conferences, Incentive Travel, Exhibitions, Corporate Hospitality and Corporate Travel. London: Pearson Education.

Fernández-Cavia, J. et al. (2017). Online communication in Spanish destination marketing organizations: The view of practitioners. Journal of Vacation Marketing, 23(3), 264-273.

Ferraro, G. (2006). The Cultural Dimension of International Business. Upper Saddle River: Person Prentice Hall.

Fiske, J. (1990). Introduction to Communication Studies. London: Routledge.

Ford, R.C. \& Peeper, W.C. (2008). Managing Destination Marketing Organization. The Tasks, Roles, Responsibiliies of the Convention and Visitors Bureau Executive. Orlando (Florida): ForPer Publications.

Gesteland, R.R. (2012). Cross-Cultural Business Behavior: A Guide for Global Management. Copenhagen: Copenhagen Business School Press.

Glinska-Newes, A. et al. (2018). Relationship-focused or deal-focused? Building interpersonal bonds within B2B relationships. Baltic Journal of Management, 13(4), 508-527.

Hall, E.T. (1976). Beyond Culture. New York: Doubleday.

Hofstede, G.H. (1997). Cultures and Organizations: Software of the Mind. New York: McGraw-Hill.

Jakobson, R. (1976). Poetyka w świetle językoznawstwa. Tłum. K. Pomorska. In: H. Markiewicz (oprac.), Wspótczesna teoria badań literackich za granica: antologia, t. 2: Strukturalno-semiotyczne badania literackie, literaturoznawstwo porównawcze, $w$ kręgu psychologii głębi i mitologii (pp. 42-47). Kraków: Wyd. Literackie.

Lasswell, H.D. (1948). The structure and functions of communications in society. In: L. Bryson (ed.). The Communications of Ideas (p. 23). New York: Harper.

Lee, H.R., Lee, J.S. \& Jones, D. (2016). Exploring the interrelationship between convention and visitor bureau (CVB) and its stakeholders, and CVB performance from the perspective of stakeholders. Journal of Travel \& Tourism Marketing, 33(2), 224-249.

McQuail, D. \& Windahl, S. (2015). Communication Models for the Study of Mass Communications. London: Routledge. 
Rogers, T. \& Davidson, R. (2015). Marketing Destinations and Venues for Conferences, Conventions and Business Events. London: Routledge.

Rogerson, C.M. (2017). Conference and exhibition tourism in South Africa. In: Urban Tourism in the Developing World (pp. 89-108). CM Rogerson. London: Routledge.

Samaha, S.A., Beck, J.T. \& Palmatier, R.W. (2014). The role of culture in international relationship marketing. Journal of Marketing, 78(5), 78-98.

Ting-Toomey, S. \& Dorjee, T. (2018). Communicating across Cultures. New York: Guilford Publications.

Tjosvold, D. (2017). Cross-cultural Management: Foundations and Future. London: Routledge.

Volgger, M. \& Pechlaner, H. (2014). Requirements for destination management organizations in destination governance: Understanding DMO success. Tourism Management, 41, 64-75. 